\title{
Review of the millipede genus Cylindroiulus Verhoeff, 1894 in the Asian part of Russia (Diplopoda: Julida: Julidae)
}

\section{Обзор диплопод рода Cylindroiulus Verhoeff, 1894 в азиатской части России (Diplopoda: Julida: Julidae)}

\author{
Pavel S. Nefediev ${ }^{1}$, Julia S. Nefedieva ${ }^{2}$ \& Yuri V. Dyachkov ${ }^{1}$ \\ Павел С. Нефедьев ${ }^{1}$, Юлия С. Нефедьева ${ }^{2}$, Юрий В. Аьячков ${ }^{1}$
}

\footnotetext{
${ }^{1}$ Altai State University, Barnaul 656049 Russia. E-mail: p.nefediev@mail.ru

${ }^{2}$ Barnaul Branch of OJSC “GIPRODORNII”, Barnaul 656000 Russia.

${ }^{1}$ Алтайский государственный университет, Барнаул 656049 Россия

${ }^{2}$ Барнаульское отделение «ГИПРОДОРНИИ», Барнаул 656000 Россия
}

KEY WORDS: Cylindroiulus, latestriatus, britannicus, truncorum, faunistics, introduction, key, Siberia.

КЛЮЧЕВЫЕ СЛОВА: Cylindroiulus, latestriatus, britannicus, truncorum, фаунистика, интродуцент, ключ, Сибирь.

ABSTRACT. This paper reviews the julid genus Cylindroiulus in the Asian part of Russia, based both on re-examined material from Tomsk City, Siberia and on some new samples. The present contribution corrects several mistakes in the identification and localization of $C$. latestriatus (Curtis, 1845) and records this species in southwestern Siberia for the first time. Both C. britannicus (Verhoeff, 1891) and C. truncorum (Silvestri, 1896) are new to the fauna of the Asian part of Russia. Remarks are provided for all these three anthropochore species, all also being keyed and mapped.

РЕЗЮМЕ. На основе переизучения материала из города Томска и изучения новых проб данная статья обобщает находки кивсяков рода Cylindroiulus в азиатской части России. Данное сообщение исправляет некоторые ошибочные определения и точки находок C. latestriatus (Curtis, 1845) и впервые отмечает этот вид на юго-западе Сибири. И $C$. britannicus (Verhoeff, 1891), и C. truncorum (Silvestri, 1896) - новые для фауны азиатской России. Для всех этих трех антропохорных видов приведены замечания, дан ключ и картирование находок.

\section{Introduction}

The taxonomic history of Cylindroiulus Verhoeff, 1894 in the Asian part of Russia commenced with Gulička's [1963] description of Cylindroiulus (Sibiriulus) dentiger Gulička, 1963, from near Prokopievsk, Kemerovo Area, southwestern Siberia. That species became the type of a new subgenus of Cylindroiulus, but later Sibiriulus Gulička, 1963 was removed from the tribe Cylindroiulini [Read, 1992] and treated in the rank of a full genus [Mikhaljova, 1993, 2004].
The first record of a true species of Cylindroiulus in East Asia (but not in entire Asia as claimed) concerned the Russian Far East, when Mikhaljova [1998a, b] reported the widespread, basically European C. latestriatus (Curtis, 1845) in the Kurile Islands. The geographically closest records actually belong to several congeners endemic to Central Asia, including eastern Kazakhstan [Read, 1994]. Mikhaljova \& Golovatch [2001] provided the second occurrence of C. latestriatus in Asia, but these authors misinterpreted the locality as lying in the Altai Mts, Siberia. This record was followed by several misidentified samples from the Tomsk Area [Mikhaljova \& Nefediev, 2003], later repeated in some subsequent publications [Nefediev, 2005a, b; Nefediev \& Nefedieva, 2006, 2011].

The material treated herein has been deposited mainly in the private collection of the first and second authors (CN), Barnaul, Russia, partly shared also with the collection of the Institute of Systematics and Ecology of Animals (ISEA), Novosibirsk, Russia. The species names include the literature references concerning the Asian part of Russia only.

Taxonomic part

Cylindroiulus latestriatus (Curtis, 1845) Map.

Cylindroiulus latestriatus — Mikhaljova, 1998a: 6; 1998b: 61, fig. non Cylindroiulus latestriatus - Mikhaljova \& Golovatch, 2001: 104; Mikhaljova \& Nefediev, 2003: 85; Nefediev, 2005a: 43; 2005b: 6; Nefediev \& Nefedieva, 2006: 98; 2011: 100

MATERIAL EXAMINED. $2 \sigma^{\top} \sigma^{\top}, 4$ +क (CN), Russia, southwestern Siberia, Altai Province, Pervomaiskii District, Beryozki Railway Station, gardens, strawberry bed, 24.07.2007; $2 \sigma^{7} \sigma^{7}, 8$ 우, 2 juv. (CN), same locality, under squash, 20.08.2007, all leg. P.S. Nefediev \& J.S. Nefedieva. 


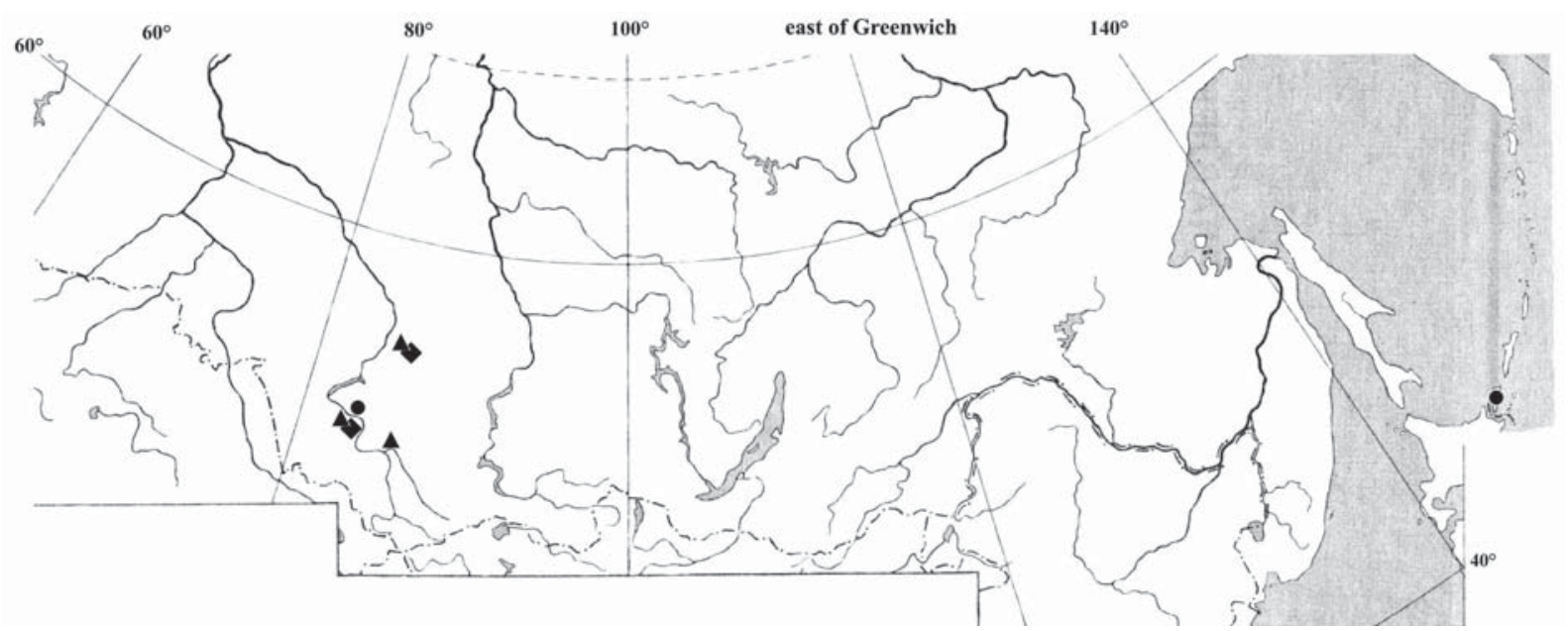

Map. The Asian part of Russia, showing the known localities of the three species of Cylindroiulus. Circle - C. latestriatus; triangle C. britannicus; diamond - C. truncorum.

Карта. Азиатская часть России с указанием мест находок всех трех видов Cylindroiulus. Кружок - C. latestriatus; треугольник C. britannicus; ромб - C. truncorum.

DISTRIBUTION. Throughout Europe, mainly synanthropic, in Great Britain, including the Channel Islands and Northern Ireland, Ireland, Denmark, including the Faroe Islands, Norway, Sweden, France, Spain, including the Canary Islands, and Portugal, including the Azores; Finland, the Netherlands, Belgium, Austria, Germany, Switzerland, Hungary, Poland, Czech Republic, Slovakia, Romania, Ukraine, Belarus, Estonia, Latvia, Lithuania, central and northwestern Russia, the Russian Far East, also introduced into Canada, the U.S.A., Mexico, and as far as Peru, Chile, St. Paul Island (Antarctic), Gough Island in the Atlantic [Blower, 1985; Mikhaljova, 2004; Enghoff, 2007].

REMARKS. The record of $C$. latestriatus by Mikhaljova \& Golovatch [2001] at Chonbiliuli, in the Altai Mts, appears to be a mistake. In fact Chonbiliuli is located not in the Altai Mts, but in the Alai Mts, namely, about $20 \mathrm{~km} \mathrm{~S}$ of Gulcha, Kyrgyzstan, Central Asia. Furthermore, the record of $C$. latestriatus by Mikhaljova \& Nefediev [2003] in the city of Tomsk is a misidentification, the species actually being $C$. britannicus (Verhoeff, 1891). Thus, the valid records in the Asian part of Russia are in the Far East: Kunashir Island, the Kuriles [Mikhaljova, 1998a, b, 2004], and in southwestern Siberia: Altai Province (see above). The species tends to dwell in anthropogenic habitats such as private grounds.

\section{Cylindroiulus britannicus (Verhoeff, 1891) Map.}

Cylindroiulus latestriatus - Mikhaljova \& Nefediev, 2003: 85; Nefediev, 2005a: 43; 2005b: 6; Nefediev \& Nefedieva, 2006: 98; 2011: 100 .

MATERIAL RE-EXAMINED: $1 \sigma^{r}, 19,5$ juv. (CN), Russia, southwestern Siberia, Tomsk Area, Tomsk City, Siberian Botanical Garden, warm greenhouse No. 1 behind pond, 10.12.1999; 11 $\sigma^{7} \sigma^{7}, 24$ 우, 26 juv. (CN), same locality, 3.03.2000; $10 \sigma^{7} \sigma^{7}, 19$ 우, 1 juv., 8 fragm. (CN), same locality, cold greenhouse No. 2,
10.12.1999; $12 \sigma^{7} \sigma^{7}, 18$ 우, 6 juv. (CN), $1 \bigcirc^{7}, 1$ (ISEA), same locality, 3.03.2000; $2 \sigma^{7} \sigma^{7}, 1$ \% (CN), same locality, 3.11.2005; 13 $\mathrm{O}^{7} \mathrm{O}^{2}, 20$ 우, 8 juv. (CN), same locality, warm and cold greenhouses Nos 1 and 2, 21.04.2000; $6 \mathrm{O}^{\top} \mathrm{O}^{\top}, 13$ 9 , 15 juv. (CN), University Grove, Betuletum near Scientific Library of Tomsk State University, 23.04.2002; 1 + 6 juv. (CN), same locality, mixed stands, 24.06.2004; 5 우 (CN), Buff-sad, Acero-Populetum, 15.05.2008, all leg. P.S. Nefediev; 1 ㅇ (CN), Siberian Botanical Garden, warm greenhouse No. 1 behind pond, pitfall traps, 28.03.-14.04.2006; 1 fragm. $(\mathrm{CN})$, rose greenhouse, pitfall traps, 28.03.-14.04.2006; 2 $\mathrm{O}^{7} \mathrm{O}^{7}, 2$ 우 $(\mathrm{CN})$, coniferous cold greenhouse, 14.04.2006, leg. P.S. Nefediev \& A.M. Folin; $1 \bigcirc^{1}(\mathrm{CN})$, Borzunov's Farm, greenhouse, no date, leg. A.S. Babenko; $3 \sigma^{7} \sigma^{7}(\mathrm{CN})$, experimental plot of Botany Department of Tomsk Agricultural Institute, open ground, 23.09.2006, leg. E.V. Miroshnichenko.

NEW MATERIAL EXAMINED. $20^{7} \sigma^{7}, 4$ 우 (CN), Russia, southwestern Siberia, Altai Province, Biysk City, cucumber greenhouse, 16.03.2010, leg. P.S. Nefediev; $3 \mathrm{O}^{7} \mathrm{O}^{7}, 3$ + $+9,3$ juv. (CN), Barnaul City, Yuzhnyi, South Siberian Botanical Garden, fern greenhouse, 19.06.2013; $1 \sigma^{7}(\mathrm{CN})$, same locality, flower greenhouse, 19.06.2013; $9 \mathrm{O}^{\top} \sigma^{\top}, 12$ 우, 9 juv. (CN), same locality, open ground with flowers and fruit trees, under boards and paving tiles of footpaths between beds, 19.06.2013; all leg. P.S. Nefediev \& Y.V. Dyachkov; 1 + (CN), Barnaul City, Populus stands, 3.07.2013, leg. P.S. Nefediev.

DISTRIBUTION. Mainly associated with human activity in Europe: mainland Norway, Denmark, Spain, including the Canary Islands, Portugal, including the Azores and Madeira; Sweden, Finland, Austria, the Netherlands, Belgium, Germany, Poland, also Great Britain, including Northern Ireland, Iceland, Ireland, Lithuania, Romania, central and northwestern Russia, Ukraine; introduced into the U.S.A. and Newfoundland, Canada, as well as South Africa, India, Brazil, and New Zealand [Lokšina, 1969; Blower, 1985; Enghoff, 2007].

REMARKS. This species is here reported from the Asian part of Russia for the first time. It seems to be the most widespread and abundant anthropochore millipede in southwestern Siberia, dwelling in anthropogenic and semi-natural habitats (greenhouses, parks, etc.) 
of the Tomsk Area (Tomsk City) and Altai Province (the cities of Barnaul and Biysk).

\author{
Cylindroiulus truncorum (Silvestri, 1896) \\ Map.
}

Cylindroiulus latestriatus - Mikhaljova \& Nefediev, 2003: 85; Nefediev, 2005a: 43; 2005b: 6; Nefediev \& Nefedieva, 2006: 98; 2011: 100.

MATERIAL EXAMINED. $10^{7}, 1$ (CN), Russia, southwestern Siberia, Tomsk Area, Tomsk City, Siberian Botanical Garden, warm greenhouse No. 1 behind pond, 10.12.1999; $1 \bigcirc^{7}, 1$ ㅇ, 1 juv (CN), same locality, 3.03.2000, all leg. P.S. Nefediev; $3 \mathrm{O}^{7} \sigma^{7}, 2$ 2 +† $(\mathrm{CN})$, same locality, coniferous cold greenhouse, pitfall traps, 29.03.- 14.04.2006; $10 \sigma^{7} \sigma^{7}, 4$ 우 $(\mathrm{CN})$, same locality, hand collecting, 14.04.2006, all leg. P.S. Nefediev \& A.M. Folin; $10^{7}$ $(\mathrm{CN})$, Altai Province, Barnaul City, Yuzhnyi, South Siberian Botanical Garden, open ground with flowers and fruit trees, under boards and paving tiles of footpaths between beds, 19.06.2013, leg. P.S. Nefediev.

DISTRIBUTION. Probably indigenous to Tunisia and Algeria, introduced into northern Europe from the Mediterranean (mainland of Denmark, France, Norway, Portugal, including Madeira; Sweden, Finland, the Netherlands, Belgium, Luxembourg, Switzerland, Germany, Austria, Hungary, Romania, Poland, Lithuania, also Great Britain, including Northern Ireland, the Canary Islands (Spain), central and northwestern Russia, Ukraine; also introduced into the U.S.A. and Brazil [Lokšina, 1969; Blower, 1985; Enghoff, 2007].

REMARKS: The above are the first reports of this species from the Asian part of Russia (Tomsk City and Barnaul City). The species has been collected only in anthropogenic habitats, but even there it seems to be rather rare.

Asian Russia appears to support three species of Cylindroiulus which can be separated using the following key.

1. Metazonites with strong and distinct longitudinal striae. Anal valves usually with more than 7 setae each, but sometimes absolutely bare. Gonopod pro- and mesomere short and squat looking, promere slightly longer than mesomere. Opisthomere with a laterad bent, smooth brachite, paracoxal process long, slender and sharply pointed, almost reaching apex of solenomere. Operculum of vulva broad, almost parallel-sided. Bursa with 13-14 setae C. truncorum

- Metazonital striae widely spaced, each anal valve usually with three submarginal setae, but sometimes absolutely bare .

.. 2

2. Light brown with darker ozadenes. Mesomere shorter than promere. Opisthomere broad, its coxal portion strongly inflated, end of opisthomere with a finger-shaped projection. Operculum symmetric, bursa with rather few setae $(6-11)$ C. latestriatus

- Light to medium brown but with rich red ozadenes. Promere and mesomere roughly the same length. End of opisthomere without finger-shaped projection. Operculum asymmetric, bursa with a numerous setae (20-29)

\section{Conclusions}

The milliped list of the Asian part of Russia includes least three species of Cylindroiulus, all anthropochore introductions: $C$. latestriatus, $C$. britannicus and C. truncorum. In Asia, the former has been registered in the Russian Far East and southwestern Siberia, as well as in Kyrgyzstan, whereas the latter two species are new to Siberia. All their records are confined to green- or hothouses in cities and to open hand-made grounds.

ACKNOWLEDGEMENTS. We are most grateful both to S.I. Golovatch (Moscow, Russia) and E.V. Mikhaljova (Vladivostok, Russia) who kindly edited advanced drafts of the paper. Our special thanks go to D.V. Logunov (Manchester, UK) for the information concerning a dubious locality.

\section{References}

Blower J.G. 1985. Millipedes. Keys and notes for the identification of the species // Synopses of the British Fauna. No.35. 242 p.

Enghoff H. 2007. Diplopoda // Fauna Europaea, version 2.0. Available from http://www.faunaeur.org (accessed 16 August 2013).

Gulička J. 1963. [New millipedes (Diplopoda) from the USSR. Part 1] // Zoologicheskii Zhurnal. T.42. No.4. P.518-524 [in Russian].

Lokšina I.E. 1969. [Keys to the millipedes (Diplopoda) of the plain areas of the European part of the USSR]. Moscow: Nauka Publ. 78 p. [in Russian].

Mikhaljova E.V. 1993. The millipedes (Diplopoda) of Siberia and the Far East of Russia // Arthropoda Selecta. Vol.2. No.2. P.3-36.

Mikhaljova E.V. 1998a. On new and poorly-known millipedes (Diplopoda) from the Far East of Russia // Far Eastern Entomologist. No.60. P.1-8

Mikhaljova E.V. 1998b. The millipedes of the Far East of Russia (Diplopoda) // Arthropoda Selecta. Vol.7. No.1. P.1-77.

Mikhaljova E.V. 2004. The millipedes (Diplopoda) of the Asian part of Russia. Sofia-Moscow: Pensoft Publ. 292 p.

Mikhaljova E.V., Golovatch S.I. 2001. A review of the millipede fauna of Siberia (Diplopoda) // Arthropoda Selecta. Vol.9 (for 2000). No.2. P.103-118.

Mikhaljova E.V., Nefediev P.S. 2003. A contribution to the millipede fauna of Siberia (Diplopoda) // Arthropoda Selecta. Vol.11 (for 2002). No.1. P.81-87.

Nefediev P.S. 2005a. [Millipedes (Myriapoda, Diplopoda) of the southeast of Western Siberia (fauna, zoogeography, ecology)]. Thesis of Candidate (Ph.D.) of Biological Sci. Degree. Tomsk. 175 p. [in Russian].

Nefediev P.S. 2005b. [Millipedes (Myriapoda, Diplopoda) of the Southeast of Western Siberia (fauna, zoogeography, ecology)]. Autoreferate of the Thesis of Candidate (Ph.D.) of Biological Sci. Degree. Tomsk: UFO-print Publ. 21 p. [in Russian].

Nefediev P.S., Nefedieva J.S. 2006. [Regional peculiarities of millipede fauna (Diplopoda) in the Southeast of Western Siberia] // Materialy X Mezhdunarodnoi shkoly-konferentsii studentov i molodykh uchenykh "Ekologiya Yuzhnoi Sibiri i sorpedelnykh territoriy". Abakan: Khakassian State University Publ. Vol.1. P.98 [in Russian].

Nefediev P.S., Nefedieva J.S. 2011. [Millipedes (Diplopoda) of the green plantations of Tomsk City and its suburbs] // Kontseptualnye i prikladnye aspekty nauchnykh issledovaniy v oblasti zoologii bespozvonochnykh. Sbornik materialov III Vserossiyskoi shkoly-seminara s mezhdunarodnym uchastiem, posvyashchennoi 120-letiyu so dnya rozhdeniya R.P. Berezhkova 
(1891-1961), Tomsk, 24-27 okt. 2011. Tomsk: Agraf-Press Publ. P.100-102 [in Russian].

Read H. 1992. The generic composition of the Cylindroiulini // Berichte des Naturwissenschaftlich-medizinischen Vereins in Innsbruck. Suppl.10. S.11-14.
Read H. 1994. The millipede genus Cylindroiulus Verhoeff, 1894 in Middle Asia (Diplopoda Julida Julidae) // Arthropoda Selecta. Vol.3. Nos 1-2. P.117-132.

Responsible editor S.I. Golovatch 